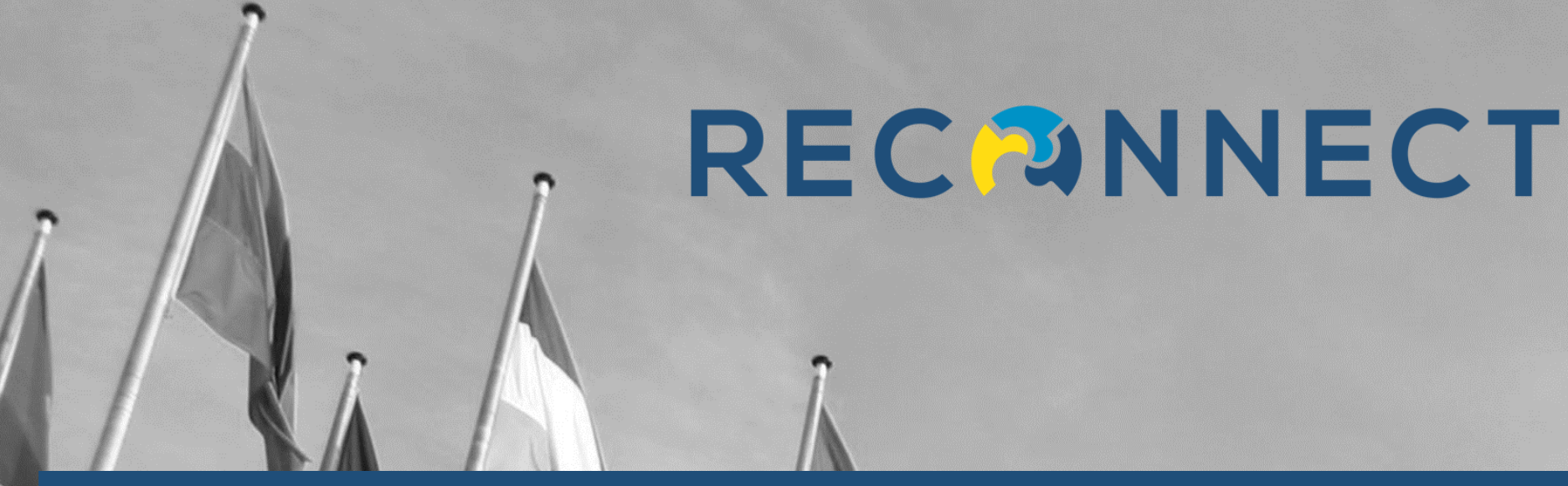

Intertwining 'Forms of Government' Between Rome and Brussels:

The Influence of EU Dynamics on the Handover from Conte I to Conte II Cabinet

Working Paper No. 13 - December 2020

Nicola Lupo

LUISS Guido Carli University of Rome

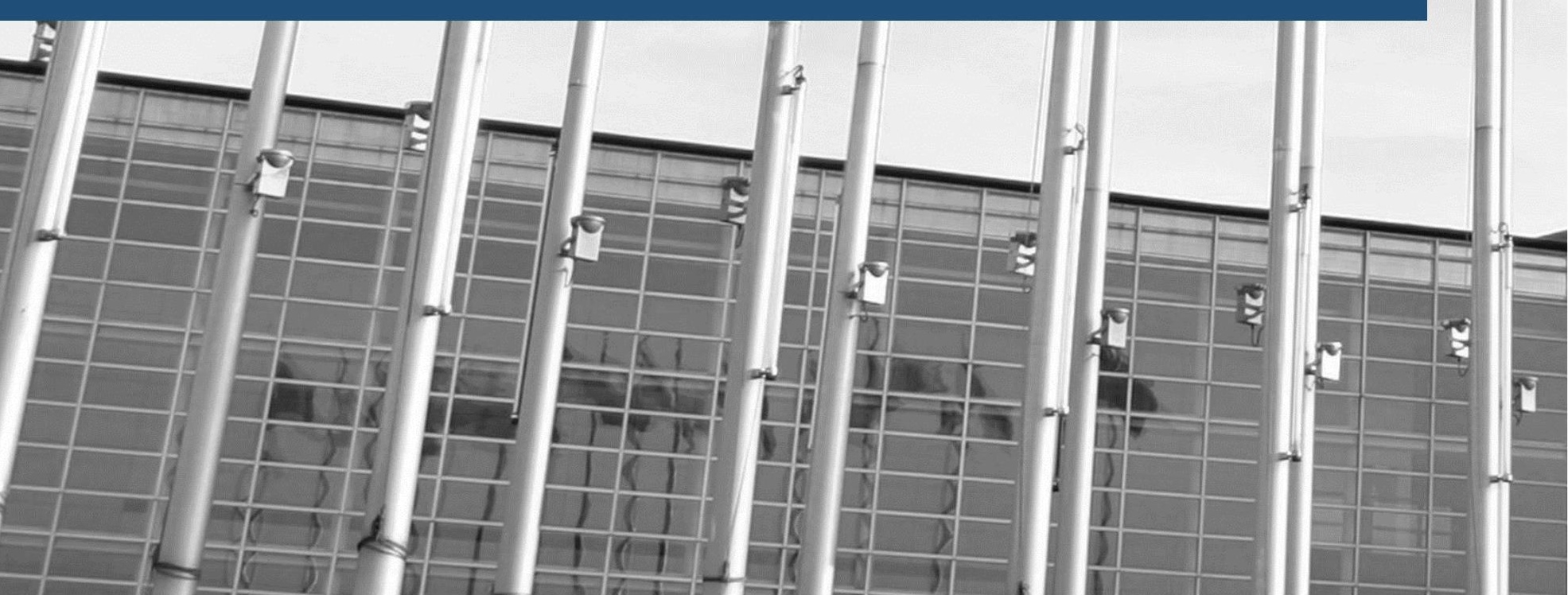




\section{DISCLAIMER}

This project has received funding from the European Union's Horizon 2020 Research \& Innovation programme under Grant Agreement no. 770142. The information in this deliverable reflects only the authors' views and the European Union is not liable for any use that may be made of the information contained therein.

\section{ACKNOWLEDGEMENTS}

The working paper partly relies on a previous article appeared in Italian in www.federalismi.it, no. 28/2020, special issue on 'II Governo. Prospettive organizzative e funzionali'. 


\title{
Intertwining 'Forms of Government' Between Rome and Brussels: The Influence of EU Dynamics on the Handover from Conte I to Conte II Cabinet
}

\author{
Nicola Lupo
}

\begin{abstract}
This working paper is based on the observation of the close intertwining between the Italian 'form of government' and the institutional dynamics of the European Union (EU). It is an intertwining that is often denied by the same political forces and public debate, but which is directly derived from how the EU institutions are designed and their close and inescapable connection with the institutions of each Member State. In the light of this assumption, the working paper analyzes the events that took place at EU level in the aftermath of the elections for the European Parliament held between 23 and 26 May 2019 and those that gave rise to the crisis of the Italian government, which occurred in August 2019, with the handover between the Conte I and the Conte II cabinet. It is argued that the events of the latter government crisis are fully understandable only in the light of the intertwining of the Italian and European 'forms of government'. The crisis was indeed determined by the different European policies of the two parties composing the yellowgreen majority and the stalemate in which the League found itself: a clear winner in the European Parliament elections in Italy, but a loser at the European level. As a conclusion, again from an institutional viewpoint, the strengthening of the Italian President of the Council deriving from its 'European role' is highlighted and confirmed, in this case, even with reference to a technocratic figure and a newcomer to Italian politics.
\end{abstract}

\section{Keywords}

European Union, Form of Government, European Parliament, European elections, President of the Council, Spitzenkandidaten

\section{Author}

Nicola Lupo is Professor of Public Law at LUISS Guido Carli University of Rome (Jean Monnet Chair on 'Understanding European Representative Democracy') and Visiting Professor at the Nicolaus Copernicus University in Toruń. 


\section{REC 3NNECT}

\section{Contents}

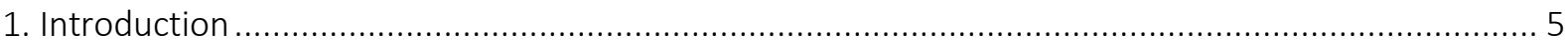

2. The intertwining between the EU and Italian 'forms of government' …..................................... 6

3. Developments in the EU 'form of government' after the May 2019 European Parliament elections . 8

4. The effects of the European Parliament elections on the Italian 'form of government': at the origins of the crisis of August 2019

5. The handover from the Conte I cabinet to the Conte II cabinet confirms the intertwining between the Italian and EU 'forms of government'. 20

6. Conclusions 23 


\section{REC INNECT}

\section{Introduction}

This working paper is based on the observation of the close intertwining between the Italian 'form of government' and the institutional dynamics of the European Union (EU). It is an intertwining that is often denied by the same political forces and public debate, but which is directly derived from how the EU institutions are designed and their close and inescapable connection with the institutions of each Member State.

In the light of this assumption, the working paper analyzes the events that took place at EU level in the aftermath of the elections for the European Parliament held between 23 and 26 May 2019 and those that gave rise to the crisis of the Italian government, which occurred in August 2019, with the handover between the Conte I cabinet, supported by a yellow-green majority (i.e., composed of the Five-Star Movement and the League), and the Conte II cabinet, which gained the confidence of the two Houses, on 9-10 September 2019, by a yellow-red majority (i.e., originally composed of the Five-Star Movement, the Democratic Party and Free and Equals, to which Italy Alive was soon added, following Matteo Renzi's split from the Democratic Party).

It is argued that the events of this crisis of government are fully understandable only in the light of this intertwining of the Italian and European 'forms of government'. In this case, a tangle that has become very problematic and substantially unsustainable for the Conte I cabinet after the result of the 2019 elections for the European Parliament. In these elections, in fact, there had been an undisputed success of the League at the national level, but also its defeat on a European scale, since the Eurosceptic forces have not been able to become decisive in the new European Parliament. Such a contrast was further highlighted after the vote by the European Parliament on Ursula von der Leyen as President of the European Commission, in which there was a very significant split between the League and the Five-Star Movement, with the votes of the MEPs of the latter as probably decisive in order to ensure the 'election' of the new President of the Commission.

A sort of short-circuit arose, in substance, between the Italian and EU 'forms of government', which would have prevented the European Parliament from voting in favour of any name the Conte I cabinet might have designated as a member of the new European Commission. On the one hand, this situation irritated the leader of the League, Matteo Salvini, who was supported by a wide consensus at home, but unable to find a way to override it. On the other hand, it ended up promoting a new political alliance, between the Five-Star Movement and the Democratic Party, formed in order to support the new Conte II cabinet, which followed a political direction much more compatible with the one that was emerging in the European Union.

The working paper makes wide use of the concept of 'form of government': a concept employed rather commonly in Italian constitutional law to refer, according to the traditional definition, to the way in which the function of political direction (indirizzo politico) ${ }^{1}$ is

\footnotetext{
${ }^{1}$ On this notion, see V. Crisafulli, Per una teoria giuridica dell'indirizzo politico, in Studi urbinati, 1939, p. $53 \mathrm{ff}$. See also T. Martines, Contributo ad una teoria giuridica delle forze politiche, Giuffrè, Milano, 1957, p. 162 ff.; E. Cheli, Atto politico e funzione di indirizzo politico, Giuffrè, Milano, 1961, p. 75 ff.; T. Martines, Indirizzo politico, in Enciclopedia del diritto, vol. XXI, Giuffrè, Milano, 1971, p. 134 ff.; M. Dogliani, Indirizzo politico. Riflessioni su regole e regolarità nel diritto costituzionale, Jovene, Napoli, 1985, p. 43 ff.; P. Ciarlo, Mitologie dell'indirizzo politico e
} 


\section{REC 3NNECT}

distributed amongst the different constitutional bodies. ${ }^{2}$ In other words, through the 'form of government', the institutional system is analysed by trying to identify the rules that govern the determination of the political direction: the way in which the main policies are designed, in the Italian case, between the executive, the Parliament and of course the citizens (in their role as voters through the electoral system), including the influence of the other constitutional bodies, namely the President of the Republic and the Constitutional Court. There has been some debate about the application of this concept to the EU institutional system, ${ }^{3}$ but this usage seems to have been rather recently 'authorised' by the Italian Constitutional Court, which registered, without hesitation, regarding the relations between the European Commission and the European Parliament, 'the undoubted transformation of the 'form of government' of the European Union towards parliamentary government'. ${ }^{4}$

\section{The intertwining between the EU and Italian 'forms of government'}

The intertwining between the Italian 'form of government' and that of the European Union derives first and foremost from how the institutional system of the Union is framed. The most significant provision is undoubtedly the one referred to in Article 10, par. 2, TEU, which expressis verbis establishes an unavoidable connection between the 'form of government' of the European Union and those of all its Member States. When this provision affirms that 'Member States are represented in the European Council by their Heads of State or Government and in the Council by their Governments, themselves democratically accountable either to their national Parliaments, or to their citizens', it is clear that the democratic legitimacy of the EU institutions also depends, physiologically and necessarily, on the good functioning of each 'form of government' of its Member States. This sets the basis, among other things, for a permanent interest, to some extent inescapable, on the part of the EU institutions, and also on the part of the other Member States, in the carrying out of orderly and correct dynamics within the 'form of government' of each Member State. ${ }^{5}$

\footnotetext{
identità partitica, Liguori, Napoli, 1988, p. 26 ff.; M. Ainis, A. Ruggeri, G. Silvestri and L. Ventura (eds.), Indirizzo politico e Costituzione. A quarant'anni dal contributo di Temistocle Martines, Giuffrè, Milano, 1998; C. Tripodina, L'indirizzo politico' nella dottrina costituzionale al tempo del fascismo, in www.rivistaaic.it, 2018, no. 1; A. Morrone, Indirizzo politico e attività di governo. Tracce per un percorso di ricostruzione teorica, in Quaderni costituzionali, 2018, no. 1, pp. $17 \mathrm{ff}$.

2 See C. Mortati, Le forme di governo. Lezioni, Cedam, Padova, 1973, p. $74 \mathrm{ff}$.

${ }^{3}$ See the different positions illustrated in R. Ibrido, N. Lupo (eds.), Dinamiche della forma di governo tra Unione europea e Stati membri, II mulino, Bologna, 2018.

${ }^{4}$ See judgment no. 239/2018 (par. 6.5, in the official translation proposed by the Constitutional Court). On it see, with different positions, G. Tarli Barbieri, II sistema elettorale per l'elezione dei membri del Parlamento europeo spettanti all'Italia: problemi e prospettive dopo la sent. 239/2018 della Corte costituzionale, in www.giurcost.org, 2019, no. 1, p. 20 ss.; G. Delledonne, 'A Goal that applies to the European Parliament no differently from how it applies to National Parliaments': The Italian Constitutional Court vindicates the 4\% Threshold for European Elections, in European Constitutional Law Review, 2019, no. 2, pp. 376-389; L. Di Stefano, La soglia di sbarramento della legge elettorale italiana per il Parlamento europeo all'esame della Corte costituzionale, in www.rivistaaic.it, 2019, no. 3; e G. Piccirilli, Attuazione dei 'principi comuni' e presunzioni di risultato nel giudizio sulla clausola di sbarramento per le elezioni europee in Italia, in Studium luris, 2019, no. 12; A. Antonuzzo, N. Lupo, The thresholds for the EP elections: the EU Electoral Act, national legislation and the case-law of Constitutional Courts, in T. Marguery, S. Platon, H. Van Eijken (eds.), Les élections européennes 40 ans après. Bilans, enjeux et perspectives. The European Elenctions, 40 Years Later. Assessment, Issues and Prospects, Bruylant, Bruxelles, 2020, pp. 119-146. ${ }^{5}$ Also for further indications, see N. Lupo, La forma di governo italiana nella forma di governo dell'Unione europea, in II Politico, 2018, nos. 2-3, pp. 41-60; Id., La forma di governo italiana, quella europea e il loro stretto intreccio
} 


\section{REC 3NNECT}

Although public statements often repeat the traditional principle of 'non-interference' by the EU institutions and those of other Member States with regard to the main political options at stake at national level (e.g., general elections, referendums, government crises, election campaigns) - usually practicing, in parallel, the easy game of 'blame shifting' to other institutional levels ${ }^{6}$ - the legal-institutional framework drawn up by Article 10, par. 2, TEU presupposes precisely that intertwining and therefore requires, to the exact opposite, a certain level of 'interference' and mutual coordination. The principle of 'non-interference', indeed, as well as other rituals still present in the European Union (e.g., the display of flags or group photos that still take place at the meetings of the European Council), appears to be the remains of ancient but persistent internationalist logics that seem completely unfit to represent the actual activity of governments, such as those of the Member States of the European Union, now closely intertwined and working together on a daily basis.

The effect of this intertwining of 'forms of government' on the balance of the Italian 'form of government' is far from negligible and affects multiple characters of the latter.

First, as has now been clearly recognised by scholars, ${ }^{7}$ the dynamics of the European Union have accentuated the role of national Governments, which can leverage the fact that they are the institutions called to represent the national interest in the decision-making process of the European Union. As is well known, it is in fact the Governments of the Member States that are entrusted with the task of identifying the national interest, obtaining it from comparison with the multiplicity of public and private stakeholders involved, and then negotiating it in the European context, so that it is properly considered throughout the decision-making process. For the Italian Government, the European Union has been a major driver of its strengthening, which has enabled it to present itself, especially in Parliament, as a reference point and guide of legislative activity in the many areas covered by EU law and also in the role of a substantial player - together with the Governments of the other Member States and the institutions of the Union - of the activity in place in the European Union, especially, but not solely, in the intergovernmental dynamics.

Second, European integration has extolled the role of the President of the Council of Ministers, who in the European Union represents and coordinates the lines of action expressed by his Government, placing this organ in a position of pre-eminence that is generally recognised to his European 'colleagues', not by chance usually referred to as 'Premier', but which has often

nella Costituzione 'composita', in S. Staiano, G. Ferraiuolo, A. Vuolo (eds.), Partiti politici e dinamiche della forma di governo, Editoriale scientifica, Napoli, 2020, pp. 159-186.

${ }^{6}$ See S.B. Hobolt-J. Tilley, Blaming Europe? Responsibility Without Accountability in the European Union, Oxford, Oxford University Press, 2014, and C. Pinelli, II doppio cappello dei governi fra Stati e Unione europea, in Rivista trimestrale di diritto pubblico, 2016, no. 3, pp. 639-649.

${ }^{7}$ See, among others, P. Perez Tremps, Il rafforzamento dell'esecutivo come conseguenza della integrazione nella Comunità europea, in G. Rolla (ed.), Le forme di governo nei moderni ordinamenti policentrici, Milano, Giuffrè, 1991, p. 93 ff.; M. Cartabia, Principi inviolabili e integrazione europea, Milano, Giuffrè, 1995, espec. p. 70 ff.; V. Schmidt, Democracy in Europe. The EU and National Polities, New York, OUP, 2006, p. 65 ff.; K.M. Johansson-J. Tallberg, Explaining Chief Executive Empowerment: EU Summitry and Domestic Institutional Change, in West European Politics, 2010, no. 2, p. 208 s.; N. Lupo-G. Rivosecchi, I limiti di un approccio esclusivamente nazionale ai problemi della forma di governo, in R. Cerreto (eds.), La democrazia italiana: forme, limiti, garanzie, Roma, Italianieuropei, 2010, p. 288 ff., espec. 293 ff.; S. Fabbrini, Governare I'Italia: il rafforzamento dell'esecutivo tra pressioni e resistenze, in II Filangieri. Quaderno 2010. Governare le democrazie. Esecutivi, leader e sfide, Napoli, Jovene, 2011, p. 33 ff.; L. Cappuccio, Forma di governo Italiana ed integrazione europea: il progressivo rafforzamento del Governo, in Diritto Pubblico Europeo. Rassegna online, 2020, no. 1, espec. p. $4 \mathrm{ff}$. 


\section{REC INNECT}

been denied to him in the Italian system. It is clear that in the European Council each Head of Government has the opportunity to be mirrored with his colleagues, thus playing a crucial role, on behalf of his country, in the planning, negotiation and definition of a set of policies that would otherwise normally fall within the competence of individual ministers. ${ }^{8}$

Third, at ministerial level, there has been an increase in the political weight of the Minister of Economy and Finance, who has played an extremely significant role in European affairs since the beginning of the 1990s, sometimes even in conflict with the role of the President of the Council. ${ }^{9}$ It has also long been characterised by a strong technical profile, so that the Minister can effectively withstand the hard and qualified confrontation that takes place, among its colleagues, in the Council of the European Union, in the ECOFIN formation, which usually meets once a month, mostly preceded by meetings of the Eurogroup. ${ }^{10}$

\section{Developments in the EU 'form of government' after the May 2019 European Parliament elections}

The 'form of government' of the European Union does not seem easy to classify and is still 'in the way of definition'. So much so that, legitimately, with reference to it - even looking at its possible future evolutions - almost all possible classifications in use for 'forms of government' have been proposed, by the scholarship, throughout the years: parliamentary (or at least quasi-

\footnotetext{
8 See, clearly, G. Amato, La funzione di governo, oggi. Relazione generale (ricordando Alberto Predieri), in Associazione italiana dei costituzionalisti, Annuario 2001, /l Governo, Padova, Cedam, 2002, p. 259 ff., espec. 266 : the enlarged context in which the Government operates enhances the role of the President of the Council. See also E. Catelani, Presidente del Consiglio e Unione europea, in L. Tedoldi (ed.), II presidente del Consiglio dei ministri dallo Stato liberale all'Unione europea, Biblion, Milano, 2020, p. 431 ff., espec. $438 \mathrm{ff}$.

${ }^{9}$ On which see L. Bartolucci, I rapporti tra presidente del Consiglio e ministro dell'economia (1992-2018), in L. Tedoldi (ed.), Il presidente del Consiglio dei ministri dallo Stato liberale all'Unione europea, cit., p. 367 ff., espec. $374 \mathrm{ff}$.

${ }^{10}$ See article 2 of the protocol no. 14 annexed to the Treaty of Lisbon. The working methods of the Eurogroup are closely coordinated with those of the 'Euro Summit'. See, among others, U. Puetter, The Eurogroup: How a Secret Circle of Finance Ministers Shape European Economic Governance, Manchester University Press, Manchester, 2006, P. Craig, The Eurogroup, power and accountability, in European Law Journal, Vol. 23, nos. 3-4, 2017, p. 234249; G. Sacriste, A. Vauchez, The 'euro-ization of Europe. Birth of a government 'at the margins' and the transformation of European policy, Revue de l'OFCE, Vol. 164, No. 4, 2019, pp. 5-46; V. Schmidt, Europe's Crisis of Legitimacy. Governing by Rules and Ruling by Numbers in the Eurozone, OUP, Oxford, 2020, espec. p. $123 \mathrm{ff}$.
} 


\section{REC 3NNECT}

parliamentary); ${ }^{11}$ semi-presidential, according to the French model; ${ }^{12}$ presidential (or at least separation of powers); ${ }^{13}$ and even directorial. ${ }^{14}$

After all, the Italian constitutional history, while the 1848 Albertine Statute was in force, shows how the 'form of government' has also been for decades 'in the way of definition': ${ }^{15}$ straddling between a constitutional charter that provided for a pure monarchical-constitutional regime, therefore a separation of powers system, and a series of behaviours and practices that pushed in the direction of a form of parliamentary government - or, according to a successful definition, 'pseudo-parliamentary' - characterised by the necessary confidence relationship between the Government and the Chamber of Deputies. ${ }^{16}$ Thus giving rise to a tension that probably never fully resolved, of which in the end the same Albertine Statute was a victim: precisely on this ambiguity, the fascist party was able to leverage to go to power, in 1922.

In the European Union, in an institutional framework at least as open, the 2019 elections of the European Parliament were expected, in particular, as a kind of 'litmus test' on the confirmation of what could be defined as a draft constitutional convention - or a constitutional convention in nuce - on the so-called Spitzenkandidaten. ${ }^{17} \mathrm{~A}$ constitutional convention aimed at making the presidency of the European Commission dependent on a comparison between the election results of the 'lead candidates' of the major European political parties. With a mechanism that,

11 For the juxtaposition of EU institutional arrangements with a form of 'quasi-parliamentary' or 'semiparliamentary' government, see A. Manzella, L'identità costituzionale dell'Unione europea, in Studi in onore di Leopoldo Elia, II, Milano, 1999, p. 923 ff., espec. 949; S. Hix, What's Wrong with the Europe Union and How to Fix It, Polity, Cambridge, 2008, espec. p. 155 ff.; P. Magnette, L'Union européenne: un regime semi-parlementaire, in P. Delwit, J.M. De Waele, P. Magnette (eds.), A quoi sert le Parlement européen?, Bruxelles, 1999, p. 25 ff.; M. Frau, La forma di governo dell'Unione nel trattato che adotta una Costituzione per l'Europa, in L. Spadacini, M. Frau, Governare I'Unione europea. Dinamiche e prospettive istituzionali, Rubbettino, Soveria Mannelli, 2006, p. 75 ff.

12 In this sense, see G. De Vergottini, Forma di governo dell'Unione europea, in XXI Secolo, Treccani, Roma, 2009 (available at: http://www.treccani.it/enciclopedia/forma-di-governo-dell-unione-europea \%28XXI-Secolo\%29/), although showing how the treaties allow the experience to concretely opt for varied solutions. As well as, more recently, J.H. Reestman, L. Besselink, Editorial, cit., p. 611.

${ }^{13}$ See, among others, A. Kreppel, Looking 'Up', 'Down' and 'Sideways': Understanding EU Institutions in Context, In West European Politics, 2011, 34:1, 167-179, espec. 169 ff., and S. Fabbrini, Which European Union?, Cambridge University Press, Cambridge, 2015, espec. p. 168 ff. and p. $177 \mathrm{ff}$.

${ }^{14}$ See T.E. Frosini, La dimensione europea della forma di stato e di governo, in www.federalismi.it, 2012, no. 5.

${ }^{15}$ The case of the Italian Albertine Statute has not been unique. In the sense that in the 'forms of government' of a large part of the Member States between the 19th and early 20th centuries there has been an evolution in a parliamentary sense, which has relied more on political practice than on the text of the constitutional charters, see. J.H. Reestman, L. Besselink, Editorial, cit., p. 609.

16 See G. Maranini, Storia del potere in Italia (1848-1967), Vallecchi, Firenze, 1967 (2nd ed., Nuova Guaraldi, Firenze, 1983), espec. p. $95 \mathrm{ff}$. On the genesis of confidence procedures in the era of the Albertine Statute see F. Rossi, Saggio sul sistema politico dell'Italia liberale. Procedure fiduciarie e sistema dei partiti fra Otto e Novecento, Rubbettino, Soveria Mannelli, 2001, espec. p. 23 ff.; M. Belletti, Forma di governo parlamentare e scioglimento delle Camere. Dallo Statuto Albertino alla Costituzione repubblicana, Cedam, Padova, 2008, espec. p. 91 ff.; and R. Ferrari Zumbini, La Torino del 1848-49 come laboratorio costituzionale: la nascita spontanea della fiducia parlamentare, in Le carte e la storia, 2016, no. 2, p. $75 \mathrm{ff}$.

${ }^{17}$ In the run-up to the election see N. Lupo, The 2019 European Parliament elections: politically crucial, but without clear institutional effects, in Perspectives on Federalism, Vol. 11, No. 1, 2019, p. 103 ff. In a not too dissimilar sense, speaking of a constitutional custom, currently in statu nascendi, C. Curti Gialdino, L'elezione di Jean-Claude Juncker a presidente della Commissione europea: profili giuridico-istituzionali, in B. Caravita (ed.), Le elezioni del Parlamento europeo del 2014, Jovene, Napoli, 2015, p. 29 ff., espec. 71 ff.; and, referring to a precarious 'political convention', L. Besselink, Introduction: A Directly Elected European Parliament, in T. Marguery, S. Platon, H. Van Eijken (eds.), Les élections européennes 40 ans après, cit., p. 9 ff., espec. 14. 
after having long been proposed in the political and doctrinal debates, had found its first application in the 2014 European elections, in which the European People's Party had obtained a relative majority of votes, and the subsequent formation of the Commission presided by JeanClaude Juncker, previously identified as the Spitzenkandidat of that party. ${ }^{18}$

This draft constitutional convention, although renewed, on the eve of the 2019 elections, by the European Parliament, with the approval of a special resolution, and by almost all the main political forces in the field, did not hold the test of the post-election. The failure derived also from its ambiguity, between a more majoritarian reading (where the lead candidate of the party that takes the most votes/multiple seats is 'elected') ${ }^{19}$ and one of a more consensual type (where the lead candidate who collects the absolute majority of seats in the EP is 'elected'). So much so that the new President of the Commission, Ursula von der Leyen, turned out to be a new and different figure compared to the Spitzenkandidaten that had been put in place.

The outcome of the European elections in May 2019 - in which there has been a significant reversal in turnout ${ }^{20}$ - has obviously weighed heavily. On the one hand, the failure of the Eurosceptic forces, which had launched a kind of takeover bid for the control of the EU institutions, has sidelined them from the process of formation of the European Commission (and, in the case of the most extreme ones, from the same distribution of offices within the European Parliament, as a result of the so-called 'cordon sanitaire' mechanism). ${ }^{21}$ On the other

${ }^{18}$ On the genesis of the Spitzenkandidaten, J. Priestley, N. Peñalver García, The Making of a European President, Palgrave MacMillan, London, 2015. On its first effects: S.B. Hobolt, A Vote for the President? The Role of Spitzenkandidaten in the 2014 European Parliament Elections, in Journal of European Public Policy, 2014, p. 1528 ff.; S. Fabbrini, The European Union and the Puzzle of Parliamentary Government, in Journal of European Integration, 2015, no. 5, p. 571 ff.; C. Antpöhler, Enhancing European Democracy in Times of Crisis? The Proposal to Politicise the Election of the European Commission's President, in F. Fabbrini, E. Hirsch Ballin, H. Somsen (eds.), What Form of Government for the European Union and the Eurozone, Hart, Oxford and Portland, 2015, p. $217 \mathrm{ff}$.; M. Goldoni, Politicising EU Lawmaking? The Spitzenkandidaten Experiment as a Cautionary Tale, in European Law Journal, 2016, no. 3, p. 279 ff.; T. Christiansen, After the Spitzenkandidaten: fundamental change in the EU's political system?, in West European Politics, 2016, p. 992 ff.; H. Kassim, What's new? A first appraisal of the Juncker Commission, in European Political Science, 2017, p. 14 ff.; E. Raffiotta, Gli Spitzenkandidaten e il necessario rafforzamento politico dell'UE, in www.federalismi.it, 2019, no. 11; S. Illari, Osservazioni sulla pratica degli Spitzenkandidaten nel contesto della forma di governo dell'Unione europea, in www.nomos-leattualitaneldiritto.it, 2018, no. 3; T. Christiansen, M. Shackleton, Spitzenkandidate 2.0: From experiment to routine in European elections?, in L. De Sio, M.N. Franklin, L. Russo (eds.), The European Parliament Elections of 2019, Luiss University Press, Roma, 2019, p. 43 ff.; C. Curti Gialdino, Dopo un difficile compromesso, fumata bianca al Consiglio europeo sui principali posti apicali nell'Unione europea, in www. federalismi.it, 2019, no. 13; K. Raube, From dawn to doom: the institutionalization of the Spitzenkandidaten process during European elections and its final negation, in S. Kritzinger, C. Plescia, K. Raube, J. Wilhem, J. Wouters (eds.), Assessing the 2019 European Parliament Elections, Routledge, London, 2020; D. Fromage, The Spitzenkandidaten procedure for the election of the European Commission President: a critical view, in T. Marguery, S. Platon, H. Van Eijken (eds.), Les élections européennes 40 ans après, cit., p. $169 \mathrm{ff}$.

${ }^{19}$ See the Gonzales Pons resolution, adopted on 7 February 2018. See also the recommendation of 14 February 2018 of the European Commission.

20 See, among others, F. Marquart, A.C. Goldberg, C.H. de Vreese, 'This time I'm (not) voting': A comprehensive overview of campaign factors influencing turnout at European Parliament elections, in European Union Politics, 2020.

${ }^{21}$ The 'cordon sanitaire' mechanism has been applied, in July 2019, against the 'Identity and Democracy' group (composed, among others, by the League and the French MEPs of the Rassemblement National of Marine Le Pen), among other things, in the election of the vice-presidents of the new European Parliament and in the distribution of offices in the bureaux of the committees. See, for everyone, A. Ripoll Servent, The European Parliament after the 2019 Elections: Testing the Boundaries of the 'Cordon Sanitaire', in Journal of Contemporary European 


\section{REC 3NNECT}

hand, the European People's Party, while remaining the first party, has retreated (getting 182 seats out of 751), making it necessary - for the first time since 1979 - for an agreement not only with the Social-Democrats, but also with at least a third force, between the Liberals and the Greens. ${ }^{22}$

In this articulated context, it was noted that the lead candidate indicated by that party, the Bavarian Christian-Social Manfred Weber, had no experience either as premier or as a minister, at national and consequently at inter-governmental politics. So it soon became clear that there was no majority in the European Council on his name. One solution could have been to appoint as President of the Commission the Spitzenkandidat of the Social Democratic Party, the Dutch Frans Timmermans, former Vice-President of the Juncker Commission. That appointment would have been in line with the more parliamentary-consensual interpretation of this draft constitutional convention: that is, to award the position of President of the Commission not to the lead candidate of the relative majority party, but to the leader of the majority coalition in the European Parliament.

However, the delicate and complex geopolitical balances of the Union have come into play here and some governments, including those of the Central and Eastern European countries (otherwise quite marginalised by the process of distributing the EU's top posts), opposed this appointment, remarking that Timmermans, within the Juncker Commission, had been in charge of policies regarding the respect of the rule of law in Hungary and Poland; an office which he had exercised rigorously, thus being unwelcome to the governments of these countries. In addition, many of the heads of state and government, including Emmanuel Macron and Viktor Orbán, willing to dismantle the Spitzenkandidaten mechanism, have explicitly pressed for a discontinuity from what happened in 2014. This discontinuity was also evidently appreciated by the European Council as an institution, in the context of its tanned tug-of-war with the European Parliament. ${ }^{23}$

To overcome this impasse, after a long negotiation, ${ }^{24}$ the solution of Ursula von der Leyen (Christian-Democrat, German), whose name was proposed by the European Council, on 2 July

\footnotetext{
Research, 2019, 15(4), pp. 331-342, espec. 338 (noting that it has only been applied to 'hard europsceptics' and not even to 'soft eurosceptics'). On similar mechanisms experienced in some European countries see W.M. Downs, How Effective is the Cordon Sanitaire? Lessons from Efforts to Contain the Far Right in Belgium, France, Denmark, and Norway, in Journal of Conflict and Violence Research, 2002, no. 1 (available at http://www.unibielefeld.de/ikg/jkg/1-2002/downs.pdf).

${ }^{22}$ See, inter alia, D. Angelucci, L. Carrieri, M. Franklin, Much ado about nothing? The EP elections in comparative perspective, in L. De Sio, M.N. Franklin, L. Russo (eds.), The European Parliament Elections of 2019, cit., p. 15 ff., and B. Crum, Party groups and ideological cleavages in the European Parliament after the 2019 elections, in S. Kritzinger, C. Plescia, K. Raube, J. Wilhem, J. Wouters (eds.), Assessing the 2019 European Parliament Elections, cit. ${ }^{23}$ On which see J. Muller Gomez, W. Wessels, J. Wolters, The European Parliament and the European Council: A Shift in the Balance of Power?, in O. Costa (ed.), The European Parliament in times of EU crisis. Dynamics and Transformations, Palgrave, Cham, 2019, p. $53 \mathrm{ff}$. On the Macron's role in dismantling the Spitzekandidaten mechanism see M. Westlake, 'Ils ne sont pas différents, ils sont à peu près les mêmes... ?' Dynamiques interinstitutionnelles post-2019 dans I'Union européenne, in O. Costa (ed.), Le Parlement européen après les élections de Mai 2019: ruptures et continuités, in Revue de l'Union européenne, 2020, no. 637 s., p. 238 ff.

${ }^{24}$ For a thorough reconstruction cf. C. Curti Gialdino, Dopo un difficile compromesso, fumata bianca al Consiglio europeo sui principali posti apicali nell'Unione europea, cit., p. $7 \mathrm{ff}$.
} 


\section{REC 3NNECT}

2019, with a qualified majority, with the curious abstention of Germany (due to the opposition to this appointment of the SPD), has come out. ${ }^{25}$

The vote of the European Parliament on the so-called 'election' of the President of the Commission, held by secret ballot on 16 July $2019,{ }^{26}$ was successful, by a rather small margin (383 votes in favour out of the 374 requested, equal to half plus one of the members), thanks to an (informal) coalition that included not only the popular, (large part of the) the Social Democrats, and the Liberals of Renew Europe, but also the Polish PiS, the Hungarian Fidesz, and the Italian Five-Star Movement (whose votes resulted as being decisive). ${ }^{27}$ With this vote the new European Parliament thus betrayed the commitment made by the same institution, in the previous composition, with the recalled Gonzales Pons resolution, not to elect any names that were not included among the Spitzenkandidaten. However, the fact that the President chosen was of the same nationality and of the same (European) political party of Weber and the active involvement of Timmermans and Vestager in the new Commission, both as executive Vice-Presidents, has led some authors to talk of a 'remodeling', according to a pragmatic and consensual reading, instead of a proper 'denial' of the Spitzenkandidaten principle. ${ }^{28}$

In the next phase, the new President of the Commission worked, together with the individual governments of the Member States, on the composition of her 'team'. ${ }^{29}$ The proposal for the appointment of commissioners is in fact the responsibility of each of the Member State, according to Article 17 TEU, but needs to be adopted by the Council, in agreement with the newly-elected President of the Commission. And then it is sent to the European Parliament, which - on the basis of what is also qualified as a constitutional convention, this time established, since 1995, in its elements both objective (the repetitio) and subjective (the

\footnotetext{
25 The SPD's opposition to the appointment of von der Leyen as President of the Commission is all the more surprising when one considers the fact that the force is a full partner of the coalition that supports the government of which von der Leyen was defence minister at the time of his appointment. This is yet more proof of the difficult intertwining of the 'forms of government' of the Union and its Member States.

${ }^{26}$ As has already been observed elsewhere (N. Lupo, A. Manzella, II Parlamento europeo. Una introduzione, Luiss University Press, Rome, 2019, p. 154), the expression 'elected' used by Art. 17, par. 7, TUE is to be considered emphatic and technically improper: it is, in fact, a power of approval, not consisting in the choice of a name among many, but in the expression of a yes or no to the 'proposal' of the European Council, formulated 'taking into account the elections to the European Parliament and after having held the appropriate consultations'. Indeed, this impropriety is also present in the German Fundamental Law (Art. 63), to which the wording adopted in the Treaty is clearly inspired, even in the alternative hypothesis (for now never occurred in either order), referred to in Art. 17, par. 7, first paragraph, third period: 'If he does not obtain the required majority, the European Council, acting by a qualified majority, shall within one month propose a new candidate who shall be elected by the European Parliament following the same procedure'.

${ }^{27}$ On the positions of the Five Star Movement within the European Parliament see S. Neri, G. Piccirilli, The FiveStar Movement and its Challenge to the Pluralistic Foundations of the Italian Democracy, paper presented in a RECONNECT workshop in Amsterdam, 19-21 February 2020, in press.

${ }^{28}$ See N. Verola, II punto di incontro. II negoziato nell'Unione europea, Luiss University Press, Rome, 2020, espec. p. $25 \mathrm{ff}$. See also M. Westlake, 'Ils ne sont pas différents, ils sont à peu près les mêmes... ?', cit., p. 243 ff., who quotes the von der Leyen's speech on $16^{\text {th }}$ July 2019, committing herself to improve the Spitzenkandidaten mechanism for the future.

${ }^{29}$ On some new features of the von der Leyen Commission see cf. G. Luchetta, Bando allo 'spin', ecco i veri equilibri di potere e il ruolo dell'Italia nella nuova Commissione Ue, in Luiss Open, 13 September 2019 (https://open.luiss.it/2019/09/13/bando-allo-spin-ecco-i-veri-equilibri-di-potere-e-il-ruolo-dellitalia-nella-nuovacommissione-ue/) and F. Furlan, La formazione della Commissione Von der Leyen, tra tradizione e innovazione, in Quaderni costituzionali, 2020, no. 1, p. $161 \mathrm{ff}$.
} 


\section{REC INNECT}

opinion iuris ac necessitatis), ${ }^{30}$ and which today is codified in a special annex to the rules of procedures of the European Parliament ${ }^{31}$ - initiates a complex and rigorous process aimed at verifying the credentials and prospected policies of the aspiring European Commissioners.

This process consists, among other things, of (a) an examination of the Commissioners' financial interests by the Legal Affairs Committee; (b) a series of hearings (lasting three hours each, of which no more than 15 minutes are devoted to the opening oral statement by the Commissioner-designate) organised by the competent parliamentary committees, preceded by a written questionnaire, to which the Commissioner is called to answer equally in writing; (c) an assessment of each Commissioner, which is entrusted to a panel composed of the chair of the competent committee and the coordinators of the political groups, so that only if a second hearing (this time of one-and-a-half hours) the coordinators who approve the Commissionerdesignate continue not to represent at least two-thirds of the members of the committee does a plenary committee vote take place; (d) finally, in any case, an assessment of the Commissioner-designate, which is expressed and communicated by a letter from the chair of the committee. All this, in fact, before the vote of approval of the new Commission by the European Parliament and its subsequent appointment by the European Council.

In the case of the von der Leyen Commission, as indeed on other occasions, the parliamentary path has been rather bumpy. ${ }^{32}$ Two proposed Commissioners, Hungary's László Trócsányi and Romania's Rovana Plumb, received a contrary assessment, motivated by conflicts of interest highlighted by the Legal Affairs Committee, before even having their hearing at the competent committee.

In the context of this phase, the most politically relevant affair was undoubtedly the rejection by the European Parliament's Joint Industry and Internal Market Committees of the authoritative name of the French Sylvie Goulard, proposed as Commissioner for Defence, Industry and Space, who received the votes against by almost all political groups except the popular and liberal. The affair, beyond the reasons for the rejection of that name (linked to a couple of investigations during her tenure as a Member of the European Parliament, which had already led to her resignation as French Minister of Defence in the first Philippe government, in 2017), was widely read as one of the European Parliament's reactions against Macron. The French President was indeed accused of having blown up the constitutional convention on the Spitzenkandidaten, as well as having achieved much, in the opinion of some too much, for the benefit of France, in the allotment of the various positions. ${ }^{33}$ However, this was certainly not

\footnotetext{
${ }^{30}$ In this sense, for example, J.H. Reestman, L. Besselink, Editorial, cit., p. 613, qualifying it as a 'convention of the constitution', and speaking of 'unwritten constitutional rule', supplementary art. 17, par. 7, third period, and art. 17, par. 8, TUE, so any action against the pre-approval rule of commissioners by the relevant parliamentary committee would be judged to be unconstitutional. On the features of that convention see R. Corbett, F. Jacobs, D. Neville, The European Parliament, 9th ed., Harper, London, 2016, p. $340 \mathrm{ff}$. On its inclusion in the enlargement of the functions of the European Parliament see A. Héritier, K.L. Meissner, C. Moury, M.G. Schoeller, European Parliament Ascendant. Parliamentary Strategies of Self-Empowerment in the EU, Palgrave, Cham, 2019, p. $61 \mathrm{ff}$.

31 The reference is to Annex VII, which is recalled by Art. 125 of the European Parliament's Rules of Procedure (available on: https://www.europarl.europa.eu/doceo/document/RULES-9-2019-07-02-ANN-07 IT.html).

${ }^{32}$ See F. Furlan, La formazione della Commissione Von der Leyen, tra tradizione e innovazione, cit., p. 161.

${ }^{33}$ See D. Fromage, The Spitzenkandidaten procedure for the election of the European Commission President: a critical view, cit., p. 175. In the sense that in doing so the European Parliament would have violated the rule of law, with dangerous repercussions on its prestige with citizens, see especially the appeal, signed by I. Pernice and other distinguished scholars, Fairness, Trust and the Rule of Law, in www.verfassungsblog.de, 21 October 2019. In the
} 


\section{REC 3NNECT}

the first time that the European Parliament, in the context of the European Commission's extensive assessment process, had rejected the name of a proposed Commissioner. ${ }^{34}$ Moreover, it should also be considered that other elements have probably played a role, including some discontent among the German MEPs, both popular and social democrat.

All this, since the European Commission can be appointed, and settled, only after obtaining Parliament's approval, resulted in the postponement - by one month - of the establishment of the new Commission (with a corresponding extension of the previous one). ${ }^{35}$ The vote of approval of the new Commission as a whole took place on 27 November 2019, by roll call, with a far greater number of votes in favour (461) than the previous vote. This vote was soon followed by the activation of the process to set up a Conference on the Future of Europe, which was also tasked with addressing 'the democratic and institutional aspects of the EU': ${ }^{36}$ thus including, possibly, the issue of transnational lists in the election of the European Parliament and the fate of the Spitzenkandidaten.

A superficial analysis could lead to the conclusion that the failure to implement the mechanism to ensure direct legitimacy to the President of the Commission - or at least its suspension - has held back the evolution towards a form of parliamentary government, ${ }^{37}$ and has led instead to prioritising the reading of the 'form of government' of the European Union in terms of the separation of powers, thus benefiting the role of the European Council and the intergovernmental dimension of the Union. ${ }^{38}$ This would encourage to pursue, in the future, a long-sustained option of disengaging the Commission from the European Parliament, qualifying it as an administrative structure serving the European Council, whose President, de iure condendo, should somehow be directly legitimised by the citizens at European level. ${ }^{39}$

Indeed, even in the light of the analysis that has been conducted so far, the picture seems rather different. With the failure to implement, this time, the constitutional convention on Spitzenkandidaten, the transformation in a parliamentary direction of the EU 'form of government' does not seem to have stopped at all, but rather has undergone a further

opposite direction, arguing that it is in the prerogatives of the European Parliament to reject a Commissionerdesignate, see E. Cannizzaro, The European Parliament at the first crusade, in www.europeanpapers.eu, 2019, No. 2, p. 423 ff., and A. Crespy, The Goulard case: a rap on the knuckles for Emmanuel Macron, in www.socialeurope.eu, 17 October 2019.

34 Starting with Rocco Buttiglione, in 2000: see, among others, L.S. Rossi, II Parlamento europeo e il 'caso Buttiglione', in Quaderni costituzionali, 2005, no. 1, p. 167 ff. e L. Spadacini, /l rafforzamento del ruolo del Parlamento europeo nella prassi. Il 'caso Buttiglione', in L. Spadacini, M. Frau, Governare I'Unione europea, cit., p. $11 \mathrm{~s}$.

35 See art. 17, par. 7, third paragraph, last period, TEU. It can be pointed out that in Italy, for example, the establishment of the new Government precedes the vote of confidence by the two Houses, which must take place, under art. 94, third paragraph, Cost. 'within ten days of its formation.'

${ }^{36}$ See the resolution adopted by the European Parliament on 15 January 2020 on its position on the Conference on the Future of Europe (P9_TA-PROV(2020)0010).

37 Cf. G.E. Vigevani, Dalle elezioni europee alla scelta del presidente della Commissione: brevissime note sull'evoluzione della forma di governo europea, in Quaderni costituzionali, 2019, no. 4, p. $917 \mathrm{ff}$.

38 Cf. S. Fabbrini, Institutions and Decision-Making in the EU, in R. Coman, A. Crespy, V.A. Schmidt (eds.), Government and Politics in the Post-Crisis European Union, CUP, Cambridge, 2020, p. 54 ff., espec. 65.

${ }^{39}$ This is, in particular, the option long indicated, albeit with different formulations, by S. Fabbrini (Sdoppiamento. Una prospettiva nuova per l'Europa, Laterza, Roma-Bari, 2017, espec. p. 155 ff.), imagining a ballot mechanism between two candidates for the post of President of the European Council (renamed 'European Presidency'), entrusted to large electors gathered in national constituencies, each equal to the number of MEPs elected in each Member State. 


\section{REC 3NNECT}

acceleration and, at the same time, an adjustment. That is, by veering - in the context of the many variants that parliamentary regimes know, in Europe but not solely - towards a model further away from the 'premiership'. ${ }^{40} \mathrm{~A}$ model which looks closer to a 'form of government' that is properly parliamentary, which in some respects resembles a 'parliamentary government with a presidential corrective' (with the European Council as a sort of powerful 'collective head of state'); ${ }^{41}$ while, for other profiles, particularly where it calls on the Commission to 'build' its parliamentary majority measure by measure, independently from any ideologic cleavage, it would even seem to recall some vein of the 'gouvernement d'assemblée' ${ }^{42}$

It should not be forgotten that in the context of parliamentary 'forms of government' - which, as is well known, then characterised all six the founding Member States of the European Communities, and are still largely dominant among the current 27 Member States ${ }^{43}$ - there are many variations in the structure of relations between Parliament and the Government. In all EU Member States, with the sole exception of Cyprus, there is a need for a confidence relationship between the Government and (at least one branch of) Parliament, but otherwise the degree of 'rationalisation' of the 'form of government' 44 varies greatly, moving from properly semi-presidential systems to much more uncertain semi-presidentialism; from majority models to consensual models; ${ }^{45}$ and from forms of 'chancellorship' to others where the head of government is little more than a primus inter pares. ${ }^{46}$

The new Commission has, in fact, appeared perhaps more dependent than others on the internal balances of the European Parliament. Of course, these internal balances of the European Parliament have their own peculiarities, and they are deeply affected - not very differently, however, from what is happening in federal experience - not only by the political orientation, but also by the MEPs election in the different Member States. In this key, it would certainly have benefited the good functioning of the relationship between the European Parliament and the Commission to allocate a share of the seats left free after Brexit through

\footnotetext{
${ }^{40}$ In the sense of calling for an evolution of this kind, giving European citizens a second vote for the President of the European Commission, see M. Dawson, Should the EU Think Twice Before Dumping its Spitzenkandidaten?, in www.verfassungsblog.de, 30 May 2019.

${ }^{41}$ In this sense, see A. Manzella, Nell'emergenza, la forma di governo dell'Unione, in Astrid-Rassegna, 2020, no. 5. ${ }^{42}$ As argued in N. Lupo, La forma di governo dell'Unione, dopo le elezioni europee del maggio 2019, in Consulta on line, 9 March 2020. In a similar sense, cf. G. Vilella, E-Democracy. Dove ci porta la democrazia digitale, Pendragon, Bologna, 2020, p. $58 \mathrm{ff}$. On the consensual nature of the dynamic in the EP see S. Bendjaballah, S. Novak, O. Rozenberg, Uni par l'adversité? Le consensus au Parlement européen, in O. Costa (ed.), Le Parlement européen après les élections de Mai 2019, cit., p. 220 ff.

${ }^{43}$ See R. Ibrido, L'evoluzione della forma di governo parlamentare alla luce dell'esperienza costituzionale dei sei Stati fondatori, in Dinamiche della forma di governo tra Unione europea e Stati membri, cit., p. 57 ff.; F. Clementi, La V Repubblica francese e il ciclo di razionalizzazioni degli anni Settanta, ivi, p. 85 ff.; M. Olivetti, II regime parlamentare nell'Europa centro-orientale dopo il 1989, ivi, p. $113 \mathrm{ff}$.

${ }^{44}$ On the concept of 'rationalised parliamentarism' see B. Mirkine-Guetzevitch, Les Constitutions de l'Europe Nouvelle, Delagrave, Paris, 1928, p. $13 \mathrm{ff}$. and $22 \mathrm{ff}$.

45 In the sense of the consensual nature of European democratic dynamics, as developed in the aftermath of the 2019 elections, see M. Dawson, The lost Spitzenkandidaten and the future of European democracy, in Maastricht Journal of European and Comparative Law, 2019, no. 6, pp. 731-735.

${ }^{46}$ It therefore seems a little forced to argue, as J.H. Reestman, L. Besselink, Editorial, cit., p. 611, do, that 'in parliamentary systems, parliamentary elections not only determine the composition of parliament, but also of the government, In for instance Austria, Bulgaria, Germany, Italy, Spain, the Netherlands and the United Kingdom, and probably in most member states, parliamentary elections also decide who becomes prime minister - though not always in an equally straightforward manner, of course'. Indeed, it suffices to refer to the Italian governments formed in the last two legislative terms (i.e., since 2013) to question this statement.
} 


\section{REC 3NNECT}

transnational lists. An opportunity that, as is well known, has not been seized, but which could soon resurface, and which would allow a share of MEPs to be institutionally called to take charge, similar to what is happening to the Commission, of the general interest of the Union. ${ }^{47}$

On the other hand, it is undeniable that the European Council, in the process of appointing the top-positions of the European institutions, has reaffirmed its role, albeit at the cost of long and deflating negotiations. However, it would be very difficult to argue that the European elections provided unique indications to appoint someone or someone else to the top of the various EU institutions. As in parliamentary 'forms of government', especially where proportional electoral systems are in place, voters are essentially limited to handing out the cards and decisions are then taken by their representatives. Representatives that are here identified not only with the Members of the European Parliament, but also by the governments of each Member State.

The events that have just been reported thus seem to determine, eventually, a reaffirmation of the 'undoubted transformation in a parliamentary sense of the form of government of the European Union', as rightly noted by the Italian Constitutional Court in the already mentioned judgment No. 239 of 2018. With a final caveat, however obvious, but which had often been ignored by the simplistic narrative aimed at obtaining 'a President directly legitimized by European voters'. In other words, in the complex democracy of the European Union, alongside the channel centred on the European elections, there is another parallel representative channel, which relies on the 'forms of government' of the Member States, and which finds its core in the Council, in its various formations, and in the European Council. This representative channel derives its democratic legitimacy, as stated by Article 10, par. 2, TEU, from parliaments and citizens of each Member State.

That is why, after all, the EU 'form of government', while clearly placed among the parliamentary systems, maintains a strong atypical position and perhaps seems best to be qualified as a 'Euro-national parliamentary system': i.e. a 'form of government' which considers not only the confidence-like relationship between the European Commission and the European Parliament, but also the relationships between each government and 'its' national parliament, on which the democratic legitimacy of the European Council and the Council relies. In this context, a progressive emergence of the different readings of the European interest and a public confrontation between them, in the European Parliament elections ${ }^{48}$ - both elements which would undoubtedly be facilitated by the existence of transnational lists and

\footnotetext{
47 See the resolution passed by the European Parliament on 7 February 2018, which excluded the idea of the establishment of a 'transnational constituency', from the borders coinciding with those of the Union, in which at least some of the 73 seats intended to be freed as a result of Brexit were excluded.

${ }^{48}$ In addition, of course, to the relations between the parliaments of different territorial levels and those, growing regularly, between the European institutions and the parliaments of the Member States. Cf. N. Lupo, Parlamento europeo e parlamenti nazionali nella Costituzione 'composita' nell'UE: le diverse letture possibili, in www.rivistaaic.it, 2014, no. 3; A. Manzella, Parlamento europeo e parlamenti nazionali come sistema, ivi, 2015, no. 3; C. Fasone, N. Lupo, Conclusion. Interparliamentary Cooperation in the Framework of a Euro-national Parliamentary System, in N. Lupo, C. Fasone (eds.), Interparliamentary Cooperation in a Composite European Constitution, Hart, Oxford, 2016, p. 345 ff.; N. Lupo, G. Piccirilli, Introduction: the Italian Parliament and the New Role of National Parliaments in the European Union, in N. Lupo, G. Piccirilli (eds.), The Italian Parliament in the European Union, Hart, Oxford, 2017, p. 1 ff.; N. Lupo, A. Manzella, II Parlamento europeo, cit., p. 125 ff. For some criticisms to this formula, supporting the one of the 'multi-level parliamentary field', see B. Crum, National Parliaments and Constitutional Transformation in the EU, in European Constitutional Law Review, 2017, no. 4, pp. 817-835.
} 
supranational seats - would help to more clearly outline a European political direction. With this political direction all the institutions involved should somehow come to terms, thus moving away from any 'assemblearistic' scenario.

\section{The effects of the European Parliament elections on the Italian 'form of government': at the origins of the crisis of August 2019}

The elections for the European Parliament in May 2019, in addition to determining the abovementioned effects on the EU 'form of government', have, as is natural, also caused a series of consequences on the Italian political and institutional system. ${ }^{49}$ So much so that the origins of the crisis of government that occurred in August 2019, with the handover from the Conte I to the Conte II cabinet, seem to stem, ultimately, from the mis-alignment between the outcome of these elections in Italy and that of the same elections on a European scale. Given the necessary connection between the two circuits of the political direction, i.e. the two 'forms of government', this mis-alignment has put in existential difficulty the Conte I cabinet and its populistic majority (called 'yellow-green', being composed of the Five-Star Movement and the League), causing a deep malaise especially in the political force of the majority, the League, which had - to put it with a hyper-synthetic formula - 'clearly won in Italy, but lost in Europe'.

For the League, and to a lesser extent for the entire yellow-green majority, in fact, the European elections in 2019 represented an opportunity to launch a double challenge. Internally, in order to attest that the votes obtained in the general elections of the previous year - when the League had presented itself in coalition with the other forces of the centre-right (Forza Italia and Brothers of Italy) and the Five-Star Movement became the first political party in Italy ${ }^{50}$ were in the meantime confirmed, if not increased (as well as in order to verify its internal distribution). At the European level, in order to try to move to the minority the traditionally dominant forces in the institutions of the European Union, to 'change Europe, after changing

\footnotetext{
${ }^{49}$ Political scientists have long qualified the European elections as 'second order elections': in the sense that such elections are considered by voters to be less important than national ones and that the voting behaviour of citizens is mainly determined by their degree of satisfaction with the action of national governments, rather than by the assessment of the actors on the EU arena. This has multiple implications, including: a) European election campaigns dominated by national themes; b) good results obtained especially by opposition parties; c) a comparatively lower turnout than in national general elections. See K. Reif, H. Schmitt, Nine Second-Order National Elections. A Conceptual Framework for the Analysis of European Election Results, in European Journal of Political Research, 1980, Volume 8, Issue 1, pp. 3-44. For a more updated picture, see S. Hix, C. Lord, Political Parties in the European Union, Palgrave, 1997, p. 87 ff.; D. Viola (ed.), Routledge Handbook of European Elections, Routledge, Abingdon, 2016; and, under an Italian perspective, L. Tentoni, Le elezioni europee in Italia. Un percorso fra storia e dati. 1979-2019, II mulino, Bologna, 2019, p. 9 ff. More recently, the picture has been questioned, although in different ways: L. Desio, L. Russo, M.N. Franklin, Explaining the outcome. Second order factors still matter, but with an exceptional turnout increase, in The European Parliament Elections of 2019, cit., p. 57 ff.; C. Galpin, H.J. Trenz, In the Shadow of Brexit: The 2019 European Parliament Elections as First-Order Polity Elections?, in The Political Quarterly, Vol. 90, No. 4, October-December 2019, pp. 664-671; C. Plescia, J. Wilhem, S. Kritzinger, First-order breakthrough or still second-order? An assessment of 2019 EP elections, in Assessing the 2019 European Parliament Elections, cit.; D. Angelucci, L. De Sio, A. Paparo, Europe matters... upon closer investigation: a novel approach for analysing individual-level determinants of vote choice across first-and second-order elections, applied to 2019 Italy, in Italian Political Science Review/Rivista Italiana di Scienza Politica, 2020.

${ }^{50}$ About the roots of the success of populist forces see G. Orsina, Genealogy of a Populist Uprising. Italy, 19792019, in The International Spectator, 2019, no. 2, pp. 50-66. See also P. Blokker, M. Anselmi (eds.), Multiple Populisms. Italy as a Democracy's Mirror, Routlegde, Abingdon, 2020, and G. Delledonne, G. Martinico, M. Monti, F. Pacini (eds.), Italian Populism and Constitutional Law. Strategies, Conflicts and Dilemmas, Palgrave, Cham, 2020.
} 


\section{REC 3NNECT}

Italy', also foreshadowing, for this purpose, a kind of international alliance of sovereigntist movements.

Well, it is easy to see that, while the internal challenge was successful, especially for what concerns the League, which registered $34.26 \%$ of the valid votes, obtaining 28 of the 73 seats available in Italy (substantially doubling the percentage of the votes obtained in the 2018 general election and more than quintupling that achieved in the 2014 European elections), ${ }^{51}$ the same cannot be said for the European challenge. In this area, in fact, the EP elections confirmed the majority of seats for the political forces in favour of European integration, while marking, for the first time, the insufficiency of only the popular and socialist-democratic parliamentarians to reach the threshold of $50 \%+1$ of the seats in the European Parliament. Matteo Salvini's League and Marine Le Pen's National Rassemblement both had a good result, but within the EP they still formed a political group (called 'Identity and Democracy') with less than $10 \%$ of MEPs.

For the rest, the election campaign of Eurosceptic forces had the effect of Europeanising the confrontation in many Member States and leading to a greater mobilisation at the ballot box, so much so that, as has already been pointed out, there was a very significant reversal in turnout, which for the first time since 1979 marked an increase, even conspicuous. The prospect of an international alliance of sovereigntist movements has proved, in many respects, a contradiction in terms, since Eurosceptic forces are very difficult to join together, as they propose an extreme pursuit of their respective national interests, which are by definition at odds with each other.

However, on the domestic side, it should be pointed out that the challenge posed by the yellowgreen majority to the traditionally dominant political forces had also resulted in a series of more institutional profiles.

Suffice it to say that, in the long-troubled formation of the Conte I cabinet - in which the antieuro positions expressed by Paolo Savona, as the proposed appointee in charge of the Ministry of Economy and Finance by the President of the Council, had led to a tough confrontation with the President of the Republic ${ }^{52}$ - the leaders of the two main majority parties had chosen for themselves not only to be senior Ministers, but also the position of Vice-Presidents of the Council. ${ }^{53}$ A position that, during the year of experience of this government, has allowed Luigi Di Maio and Matteo Salvini to not be fully involved in the 'co-government' that almost on a

\footnotetext{
${ }^{51}$ See. A. Chiaramonte, L. De Sio, V. Emanuele, Salvini's success and the collapse of the Five-star Movement: The European elections of 2019, in Contemporary Italian Politics, 2020, no. 2, pp. 140-154.

52 On the so-called 'Savona case' the literature is conspicuous, also in English. See D. Tega, M. Massa, Why the Italian President's Decision was Legitimate, in VerfBlog, 28 May 2018, M. Fichera, The People vs. the Elite: Italian Dialectics and the European Malaise, in VerfBlog, 28 May 2018, M. Dani, A.J. Menendez, The 'Savona Affaire': Over-constitutionalization in Action?, in VerfBlog, 31 May 2018, G. Piccirilli, Is the institutional crisis in Italy over? Surely a storm, maybe indicating a climate change, in IACL-AIDC blog, 7-8 June 2018, and A. Torre, Taming the Crisis, Part III of the I-CONnect Symposium. The Aftermath of the Italian General Election of March 4, 2018, in IConnectblog.com, 16 August 2018. On the critical aptitute towards the Euro of the Conte I cabinet see R. Di Quirico, Challenging the Euro: The politics of anti-Euro parties in Italy during the first Conte government, in Contemporary Italian Politics, 2020.

${ }^{53} \mathrm{See}$, also for accurate references to the previous Vice-Presidents of the Council in the history of the Republic, G. Tarli Barbieri, Vicepresidenti o Co-presidenti del Consiglio? Alcune notazioni sparse su una carica controversa, in Rassegna parlamentare, 2019, no. 2, p. 369 ff.
} 


\section{REC 3NNECT}

daily basis takes place within the European Union institutions. ${ }^{54}$ In fact, as these figures were not called upon - unlike the President of the Council - to participate in the European Council, the political activity of the two leaders and, to some extent, their ministerial action have also been able to move, especially in terms of public statements, with greater freedom, being apparently more autonomous from the political direction determined by the European Union.

At first, the two Vice-Presidents of the Council seemed to benefit from this dis-association. These, in fact, even by leveraging Giuseppe Conte's lack of institutional experience and the absence of his own political legitimacy, seemed able to transform the necessary and relevant European dimension of the role of the President of the Council - which, as has been mentioned, has so far been peacefully regarded as added-value - almost as a kind of handicap. ${ }^{55}$ The President of the Council, in this initial phase, acted more 'as an arbitrator rather than elaborating on and pushing forward consistent policy lines'. ${ }^{56}$

After a few months, however, the picture changed. On the one hand, it became clear that this greater freedom of movement in public debate for the two Vice-Presidents of the Council was only apparent because the basic guidelines of government action, especially in terms of its economic policy, were nevertheless to move - even in order to avoid disrupted reactions in the financial markets - in line with the commitments long foreshadowed and agreed in the European Union. In addition, the President of the Council, mostly in tune with the Minister of Economy and Finance, Giovanni Tria, has made his case for the European institutions, and in particular the European Council, and on relations with other EU (and extra-EU) Heads of government in order to progressively strengthen his position within the Italian Executive. ${ }^{57}$

In this way, in the election campaign for the European Parliament and, above all, at the time of the formation of the new European Commission, the President of the Council managed to bring back the Five-Star Movement (at least most of it) to more pro-European positions. And, then, to equip itself with a greater institutional force, ${ }^{58}$ able to withstand the frontal attack launched, at the beginning of August 2019, by Matteo Salvini and even to legitimise his stay at the head

\footnotetext{
${ }^{54} \mathrm{See}$, also for references to the underestimation of the role of the CIAE (Interministerial Committee for European Affairs), whose (few) meetings were attended by the Vice-Presidents of the Council and not the President of the Council of Ministers, E. Catelani, Presidente del Consiglio e Unione europea, cit., p. $446 \mathrm{ff}$.

${ }^{55} \mathrm{See}$, for example, A. D’Andrea, Del ridimensionamento per contratto del ruolo del Presidente del Consiglio (e di altre forzature imposte dai capipartito), in Quaderni costituzionali, 2018, no. 3, p. 681 ff., espec. 685; S. Staiano, La forma di governo nella Costituzione come norma e come processo, in F. Musella (ed.), II governo in Italia. Profili costituzionali e dinamiche politiche, II mulino, Bologna, 2019, p. 29 ff., espec. 67 ff., comes to speak of the President of the Council as 'an executor in the strict sense of the dictates of the consulate (formally) vice-presidential, with functions sometimes as 'facilitator' of mediation between the two components of the diarchy'.

${ }^{56}$ See G. Delledonne, Populism and Government: Continuity and Paradoxes in the Yellow-Green Experiment, in G. Delledonne, G. Martinico, M. Monti, F. Pacini (eds.), Italian Populism and Constitutional Law. Strategies, Conflicts and Dilemmas, cit., pp. 135-151, espec. p. $146 \mathrm{ff}$.

${ }^{57}$ Similarly, see G. Grasso, Forma di governo, convenzioni costituzionali e mutamento del quadro politico, in Rivista del Gruppo di Pisa, 2019, p. 134 ff., espec. 159, who also recalls the case of the revocation of the undersecretary Armando Siri, which took place in May 2019. Cf. also L. Gianniti, B. Guastaferro, The New Italian Government between Break and Continuity, in C. Rauchegger, A. Wallerman (eds.) The Eurosceptic Challenge. National Interpretation and Implementation of EU Law, Hart, Oxford, 2019, p. 47 ff., espec. 49 ff., noting the 'strong mismatch between the Eurosceptic tone of the political discourse surrounding the 2018 elections and the institutional attitude and practices of Prime Minister Conte almost in line with the European guidelines'.

${ }^{58}$ See L. Gianniti, B. Guastaferro, The New Italian Government between Break and Continuity, cit., p. 63, observing the fact 'that the Prime Minister is the only person entitled to represent Italy in the European Council and in the Eurogroup meetings progressively strengthened Prime Minister Conte as the leader of the government'.
} 


\section{REC 3NNECT}

of a new government supported by a very different majority than the previous, and characterised by a political direction clearly more in line with that co-determined in the European Parliament. ${ }^{59}$

It was precisely the weeks after the European elections in which the political forces of the majority redefined their line, in the light of the indications given by the electorate. ${ }^{60}$ On the one hand, the Five-Star Movement understood that if it confirmed its Eurosceptic line it would end up losing further support, to the benefit of the League, as well as opposition forces such as Brothers of Italy, and therefore tried to differentiate itself as much as possible from the its partner, especially concerning the European policy. On the other hand, the League found itself at a dead end, because the consensus obtained in Italy, which clearly made it the first party, was not matched by a corresponding parliamentary strength, so it would have been very difficult to achieve a reversal of forces, in relation to the Five-Star Movement, both in terms of the ministerial team, as well as, above all, in terms of political direction.

\section{The handover from the Conte I cabinet to the Conte II cabinet confirms the intertwining between the Italian and EU 'forms of government'}

On the institutional level, the mis-alignment between the Italian result and the European result of the 2019 EP elections determined a major effect. The moment in which the intertwining of the two 'forms of government' became clearer was that of the formation of the new European Commission and in particular of the appointment of the European Commissioner by the Italian Government.

It has emerged that whatever name had been indicated by the Conte I cabinet would have found it highly unlikely both to obtain the consent of the President of the Commission and, above all, to pass the aforementioned verification procedure in the European Parliament. Indeed, if the indications descended from the internal outcome of the European elections had been followed and if - as it seemed, on the basis of informal agreements within the majority coalition - as the holder of that post a representative of the League had been indicated by the Italian Government, against him/her the already recalled 'cordon sanitaire' would have been activated. This means that a mechanism of a conventional nature - whose legitimacy is, of course, fiercely contested by the Eurosceptics, which are its main victims - would have been applied, excluding the Eurosceptic political forces, among which the League, from the most significant positions in the EU institutions, and even from the distribution of internal offices in the European Parliament, traditionally divided proportionally, on the basis of the d'Hondt method, among the main political groups. In other words, a reaction would in all likelihood be

\footnotetext{
59 Operation which was previously achieved uniquely by Alcide De Gasperi, in May 1947, and also by Giulio Andreotti, in 1979: see B. Caravita, I governi Conte: aspetti problematici di diritto costituzionale, in www.osservatorioaic.it, n. 2019, no. 5, p. 9 ff.; and M. Olivetti, Osservazioni sparse e qualche numero sulla crisi di governo dell'agosto-settembre 2019, in prospettiva storica, in www.federalismi.it, 2019, no. 16, p. $14 \mathrm{ff}$.

60 See A. Lauro, La declinazione del sistema parlamentare italiano nella XVIII legislatura. II mutamento della maggioranza governativa e la conferma del Presidente del Consiglio, Cacucci, Bari, 2020, espec. p. 83 ff. and D. Coduti, Il ruolo dei partiti politici nella transizione tra i due Governi Conte: spunti sui possibili sviluppi del sistema politico-rappresentativo, in www.forumcostituzionale.it, 2020, n. 2.
} 


\section{REC 3NNECT}

triggered to exclude the most hardline Eurosceptic forces, considered anti-system, from what has effectively been called the 'European constitutional arch' ${ }^{61}$

In short, Salvini's summer nervousness and the option, which turned out to be ineffective, to undermine the Conte I Cabinet's majority, by filing, on 9 August 2019, a motion of no confidence in the Senate (curiously, without formalising the resignation of the League's ministers), ${ }^{62}$ in order to reach an early election, stems from an institutional framework in which for the League, although the clear winner in Italy of the European elections, it was essentially impossible to influence the political direction and the structures of the Italian Government, to an extent even vaguely corresponding to the consensus obtained. On the contrary, it became more evident, especially after the formation of the von der Leyen Commission and with the possibility of an exit route to the long-standing issue of Brexit, that the outcome of the European elections would lead to a new impetus to the policy of European integration, and therefore a weakening of the strongly Eurosceptic position expressed by the League and partly, especially at its early stage, by the whole Conte I cabinet. ${ }^{63}$

That is why it can be argued that the origins of the break-up of the two partners of the populist parliamentary majority supporting the Conte I cabinet need to be found not in the split the between the Five-Star Movement and the League registered in the long-awaited vote in the Italian Senate of the motions on the Turin-Lyon high speed train, on 8 August 2019, at the immediate eve of the crisis of government, ${ }^{64}$ but in a vote that took place in the European Parliament: the vote held in Strasbourg on 16 July 2019, when the MEPs of the League betrayed the official commitment made by the President of the Italian Council, to elect Ursula von der Leyen as President of the European Commission. ${ }^{65}$

It might be objected from the perspective welcomed by some, that all this might demonstrate the irrelevance of the vote of the Italian citizens, as expressed on 26 May 2019. However, it is

\footnotetext{
${ }^{61}$ For this formula, which adapts the one ('arco costituzionale') rather consolidated in Italy to define the political parties who voted in favour of the Italian Republican Constitution in 1947, see A. Manzella, C'é il Parlamento contro i pieni poteri, in La Repubblica, 17 August 2019; B. Caravita, I governi Conte: aspetti problematici di diritto costituzionale, cit., p. $7 \mathrm{ff}$. The latter also advances a parallel with the conventio ad excludendum, applied with regards to the Italian communist party since 1947: a parallel that may certainly be the case in the common conventional nature, but which only holds up to a certain point, since in the EU Eurosceptics political forces are denied participation not only in the Executive, but also in the management of Parliament. This has never happened in Italy, so much so that the Italian communist party, although excluded from the composition of the Government till the Nineties, was always represented in the top positions of the Italian Chamber of Deputies and the Italian Senate.

62 This motion of no confidence overlapped with the motion of individual no confidence that had been tabled in the previous days by the Democratic Party against Minister Salvini (originally scheduled for September 12). From this, and the consequent split of the Conference of Group Leaders in the Senate, the convening of a meeting of the Senate on 13 August 2019 in order to vote (and reject) the proposals to change the calendar set by President Alberti Casellati submitted by the League and Brothers of Italy; and, in accordance with this calendar, the convening of the meeting of 20 August 2019, on 'Communications of the President of the Council of Ministers', in which a direct and rather theatrical Conte-Salvini confrontation took place and the President of the Council announced his resignation. See A. Lauro, La declinazione del sistema parlamentare italiano nella XVIII legislatura, cit., p. $96 \mathrm{ff}$.

${ }^{63}$ On the European policy of the Conte I cabinet see S. Fabbrini, T. Zgaga, Italy and the European Union: the discontinuity of the Conte government, in Contemporary Italian Politics, 2019, no. 3, pp. 280-293.

${ }^{64}$ See M. Cerioni, L'anaciclosi dei governi 'Conte l' e 'Conte II', in Diritto e società, 2020, no. 2, p. 325 ff., espec. p. $336 \mathrm{ff}$.

${ }^{65}$ In this sense, see A. Manzella, C'è il Parlamento contro i pieni poteri, cit.
} 


\section{REC 3NNECT}

quite easy to reply that in a constitutional democracy popular sovereignty is exercised according to the telling formula employed by Article 1 of the Italian Constitution - in the forms and ways set out in the Constitution. A similar principle can also be found at the level of the European Union, whose democracy is expressly qualified as 'representative' by Article 10, par. 1, TUE ('The functioning of the Union shall be founded on representative democracy'). Therefore, in accordance with these principles, it is through the election of their own representatives that citizens have the opportunity to contribute to the determination of the political direction in the Euro-national parliamentary system. With the elections for the European Parliament, therefore, the Italian citizens were called upon to express themselves on the guidelines to be taken within the Union, and in this they moved in contrast to the rest of the EU Member States, where, as mentioned, the Eurosceptic forces did not obtain a particularly significant increase and were not relevant in the process of forming the new Commission. ${ }^{66}$

The main critical argument would therefore be to call for the early dissolution of the Houses and the consequent use of new elections, following the change in the direction of the Italian citizens between the general elections and the EP elections. However, it is well-known that an early dissolution of the Houses, according to the interpretation widely prevalent and experienced in practice (with the sole exception, perhaps, of the dissolution of 1994), can legitimately take place only at the time when the Chamber and Senate are not able to express confidence in any government. Therefore, elements such as those drawn from local or European elections can, at most, come to prominence as ad adiuvandum arguments, but not as reasons suitable to justify an early dissolution of the Houses. ${ }^{67}$ What is important, in this logic, is that in the aftermath of the resignation of the Conte I cabinet the new yellow-red majority has emerged in an explicit form, even quickly enough to lead to the swearing-in of the new Government on 5 September 2019. A process that happened much faster than that by which, in 2018, at the beginning of the legislative term, the political agreement was found, with the conclusion of the related 'government contract' between the Five-Star Movement and the League, for the purpose of the formation of the yellow-green majority.

Nor, finally, can the risk of a sort of rebound ('ribaltone') be evoked: that is, a radical change in the alliances presented before the voters in the general election. It is almost needless to mention, in fact, that even the yellow-green majority formed in 2018, like the one aggregated the following year, was rather far from the coalitions that had been proposed in the Italian elections in March 2018. After all, the artificial nature of the political majorities supporting the Government must be considered a physiological element of the parliamentary 'form of government', especially once the option of a predominantly majoritarian electoral system has

\footnotetext{
66 See M. Esposito, L'Unione Europea: dal miraggio della federazione a fini perequativi al consolidamento dell'egemonia dei 'più uguali', in DPCE-on line, 2020, p. 2753 ff., espec. 2797, who underlines, in a polemical key, the closer connection of the Conte II cabinet with the new European Commission and speaks of a confidence relationship with the European institutions. Similarly, noting that, in parliamentary systems, the Government/Parliament confidence bond has doubled, as, alongside the traditional link, international/European ties have been added with the European Commission, see L. Melica, Le 'fatiche' europee del Governo Conte 2, in www.osservatorioaic.it, 2019, no. 5, p. $28 \mathrm{ff}$.

${ }^{67}$ In this sense see the classic handbook by C. Mortati, Istituzioni di diritto pubblico, Cedam, Padova, 1976 ${ }^{9}$, t. II, p. 665 ff. See also B. Caravita, I governi Conte: aspetti problematici di diritto costituzionale, cit., p. 9.
} 


\section{REC INNECT}

been abandoned and when the elections have not outlined a clear 'winner', able to express a majority in the two branches of Parliament.

\section{Conclusions}

A final note can be formulated, in conclusion, with reference to the institutional role of the President of the Council. The 'hold' in the face of Salvini's challenge, launched on 8 August 2019, Conte's birthday, and the 'survival' of Giuseppe Conte as President of the Council of a new cabinet, supported by a parliamentary majority other than the original, surprised many observers. All the more so given his political inexperience and also in light of the weakening of the 'technocratic' component registered in the new cabinet, in which the technocratic Ministers of the Economy and Finance and Foreign Affairs, Tria and Moavero Milanesi respectively, had been substituted by fully political figures, Gualtieri and Di Maio. A change that was only partially compensated by the appointment of a technocrat, Lamorgese, as Minister of the Interior, in substitution of Salvini.

Indeed, it is a phenomenon that finds at least some of its roots in the repeatedly recalled intertwining between the Italian and EU 'forms of government'. As has been mentioned, Conte has been able to leverage precisely the role played in the European meetings, in particular during the long negotiations that accompanied the approval of the Italian budget law in Autumn 2018 and for the identification of the holders of the top European offices that were renewed in the second half of 2019, as well as at the G7 summit held in Biarritz on 24-26 August 2019, in the midst of the Italian political crisis, in order to present itself as a credible interlocutor.

Not only was he a good mediator in the past, but also someone able to represent, in the future meetings, the positions of the new majority, too. In other words, the permanence of Conte as President of the Council guarantees a personal continuity, notwithstanding a political discontinuity: a personal continuity useful, on closer inspection, both from the point of view of the Five-Star Movement, which had designated him as premier in Spring 2018 and that in this way could alleviate the diffused concerns related to the radical change of alliances, as well as from the point of view of the European partners, who benefited from the fact that they could continue to work together with the group of people who had already taken, on behalf of Italy, a series of commitments and had actively participated, in the weeks immediately before, in the negotiations for the formation of the new European Commission.

In essence, when looking at these events with hindsight, one of the mistakes made by Salvini's League, and also by some sectors of the Five-Star Movement, was to underestimate the institutional dynamics, and in particular the European dimension of the Italian Government. A dimension that has been seen to be derived from the existing rules and which the President of the Council has been able to leverage in order to hold on, resisting to an all-political menace. A resistance that represents a further confirmation of the strengthening of the Italian President of the Council of Ministers deriving from the European dynamics. 


\section{REC INNECT}

RECONNECT, led by the Leuven Centre for Global Governance Studies, brings together 18 academic partners from 14 countries.
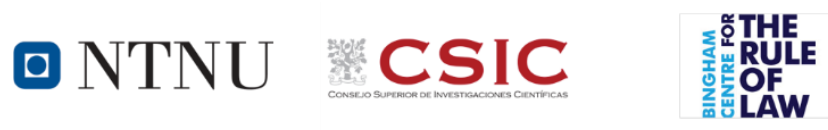

$\because$ CEU CENTRAL
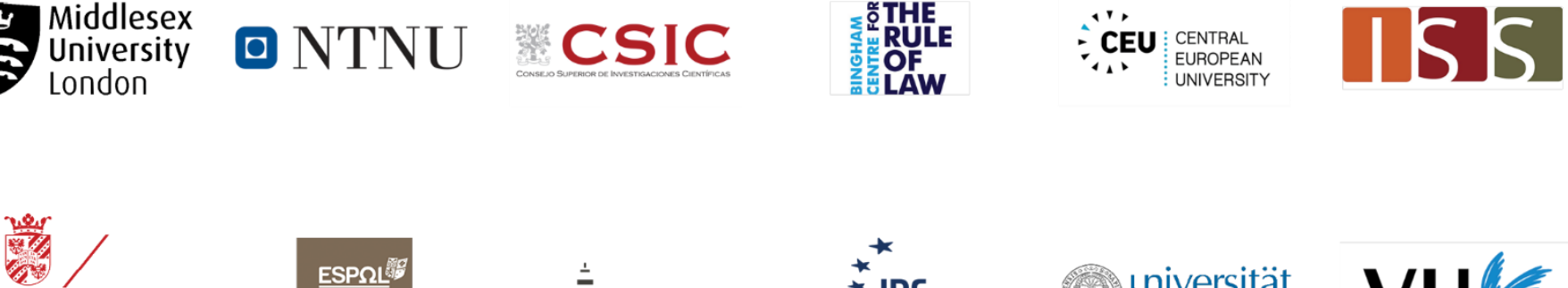

university of

groningen
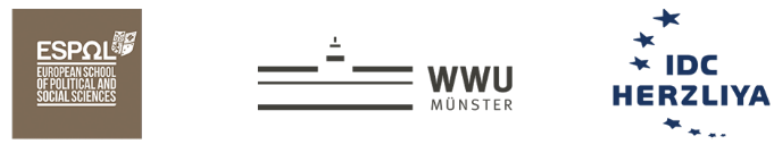

wniversität

$\mathrm{Vu}$

university college
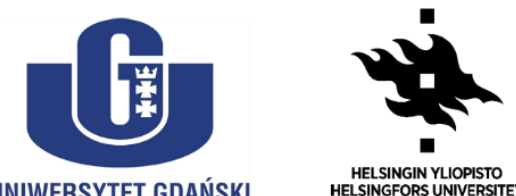

圈圈 UNIVERSITY OF CAMBRIDGE

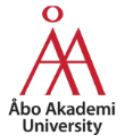

KU LEUVEN

UNIWERSYTET GDAŃSKI

HELSINGFORS UNIERSITET
UNINERSTTY OF HELSINKI

Find out more about the RECONNECT project at

www.reconnect-europe.eu

y $\mathrm{R}^{\mathrm{G}}$ 의 f 